\author{
우유로부터 Osteopontin의 분리 - 정제 및 특성에 관한 연구 \\ 최기원*김동운**.이수원* \\ 성균관대학교 식품·생명자원학과*, 축산기술연구소**
}

\title{
Purification and Properties of Osteopontin from Bovine Milk
}

\author{
K. W. Choi*, D. W. Kim** and S. W. Lee* \\ Department of Food and Life Science, Sungkyunkwan University*
}

National Livestock Research Institute, RDA**

\begin{abstract}
The purpose of this study is to observe purification and properties of osteopontin(OPN) from bovine milk. The purification of osteopontin from bovine milk was performed by using ion-exchange and hydrophobic chromatography. SDS-PAGE analysis revealed that the protein migrated at Mw. 60,000. $\mathrm{NH}_{2}$-terminal sequence analysis of the first seven amio acids revealed the protein to be identical to that previously reported for bovine OPN. 35-wk-old chickens, including 3 Single Comb White Leghorn (SCWL), were used to produce egg yolk antibody(IgY) against OPNas a antigen. However, the anti-OPN antibody activities determined by ELISA. Immunological assy of OPN in milk was performed using radial immunodiffusion test based on the standard curve of pure OPN. The radial precipitation lines of four different milk samples indicated that the concentrations of OPN in the milk samples were within the range of 31.7 to $39.7 \mu \mathrm{g} / \mathrm{ml}$. On inhibition with OPN on precipitation of calcium phosphate, OPN was slightly higher than casein phosphopeptide(CPP) and poly-glutamic acid.
\end{abstract}

(Key words : Osteopontin, Anti-OPN, Radial immunodiffusion, CPP, Calcium phosphate)

\begin{tabular}{|c|c|}
\hline I. 서 & $\begin{array}{l}\text { 현재 알려진 우유 중의 칼슘흡수 촉진물즐 } \\
\text { casein phosphopeptide(CPP)는 칼슘과 화학즈 }\end{array}$ \\
\hline 우유는 칼슘공급원으로써 많은 식품 중에서 & 로 결합할 수 있는 negative charge를 \\
\hline 도 으뜸가는 식품이다. 우유 및 유제품 중의 & phoserine(Ser-P)을 함유하고 있다(Abd El-sa \\
\hline 칼슘은 이용률이 매우 높아 가장 우수한 칼슘 & 등, 1996). CPP는 칼슘과 \\
\hline 공급식품으로 주목받고 있다(Bergeim 1926; & 하기 때문 \\
\hline Kline 등, 1932). 이것은 우유 내에 존재하는 & (Bronner, \\
\hline 칼슘 결합단백질 및 우유단백질인 casein 자체 & 1958 \\
\hline $\begin{array}{l}\text { 가 칼슘 흡수에 영향을 주기 때문으로 보고 되 } \\
\text { 어있다(Bronner, 1987). }\end{array}$ & $\begin{array}{l}\text { 의 펩타이드 분자 내에 존 } \\
\text { 이 결합됨으로서 칼슘의 }\end{array}$ \\
\hline
\end{tabular}

Corresponding author: S. W. Lee, Department of Food and life Science, Sungkyunkwan University, 300, Chunchun-dong, Jangan-gu, Suwon, Kyunggi-do, Korea. Tel: 82-031-290-7805 Fax: 82031-290-7815 E-mail: leesw@skku.edu 
(Kitts와 Yuan, 1992).

우유 중에는 $\mathrm{CPP}$ 이외에 칼슘흡수촉진물질 로 예상되는 물질 중 하나가 osteopontin(OPN) 이다. $\mathrm{OPN}$ 의 분자량은 약 $60 \mathrm{kDa}$ 이고, 아미노 산분석으로 27 개의 phosphoserine, 1 개의 phosphothreonin과 3 개의 O-glycosylation을 가지고 있는 것으로 확인되었다(Sorensen과 petersen, 1995). OPN은 무기물화된 소의 뼈에서 처음으 로 발견되었고(Franzen과 Heinegard, 1985), 그 후 rat(Oldberg 등, 1986), human(Fisher 등, 1987), mouse, pig, chicken 등에서 분리되었으 며 우유에서도 발견되었고(Sorensen과 petersen, 1993), 최근 콩팥을 비롯하여 소화관상피, 자궁, 난소, 피부 등 매우 다양한 조직에 분포하고 있음이 알려졌다(Brown 등, 1992). 처음에는 $\mathrm{OPN}$ 이 뼈에만 특이적으로 존재하는 물질이며 그 기능도 $\mathrm{RGD}$ 의 아미노산 서열을 통해 단순 히 뼈세포를 기질에 붙여주는 것으로만 생각하 였으나(Reinholt 등, 1990), $\mathrm{Ca}$ 의 조절, 무기물화 된 조직의 형성과 형태를 고쳐주고 격자구조의 결정으로 발달된 분열을 통하여 산화칼슘염의 결정의 성장을 억제 및 세포 손상시의 방어기 전을 돕고, 질소를 포함하는 산화물 생산에 영 향을 주는 등 매우 다양하다는 사실이 발표되 었다(Denhardt와 Guo, 1993). 이러한 기능들 중 많은 부분이 칼슘에 의해 매개되거나 칼슘의존 성인 여러 가지 과정과 밀접한 관련을 가지고 있다(Zimolo 등, 1994; Shirga 등, 1992). 그러나 아직도 우유에 존재하는 $\mathrm{OPN}$ 의 생리적 기능에 대해서는 분명히 밝혀져 있지 않다. 한편 OPN 의 분자구조에는 특이하게도 phosphoserin이 27 개나 존재하며 이것은 $\mathrm{CPP}$ 와 같이 칼슘과 반 응성을 생각할 수 있으며, 소장 내에서 칼슘을 수용성으로 존재시킬 가능성이 크다.

본 실험은 우리가 섭취하고 있는 우유 중 칼 슘흡수에 기여되는 예상 물질인 osteopontin을 우유에서 분리하고 그 특성을 조사해서 식품소 재로서의 응용을 목적으로하는 기초 자료로 사 용하고자 실시하였다.

\section{․ 재료 및 방법}

\section{Osteopontin의 분리·정제}

$\mathrm{OPN}$ 의 분리 - 정제는 Bayless 등(1997)의 방 법에 준하여 사용하였다. $1 \ell$ 의 원유를 12,000 $\times \mathrm{g}$ 로 15 분간 원심분리한 후 지방층을 제거하 여 탈지유를 제조하였으며, ion-exchange chromatography인 DEAE-Sephacel과 hydrophobic chromatography인 Phenyl-Sepharose 2개를 사용 하여 $\mathrm{OPN}$ 을 분리 - 정제하였다. 분리한 분획은 $280 \mathrm{~nm}$ 에서 흡광도를 측정한 후 $10 \% \mathrm{SDS}-$ $\mathrm{PAGE}$ 를 이용하여 분리 정도를 확인하였다. 확 인된 분획은 $\mathrm{Mw} .25,000(\mathrm{Spectra} / \mathrm{pr}, \mathrm{USA})$ 의 dialysis membrane을 이용하여 생리식염수에 48 시간 동안 투석한 후 동결건조하여 $-20^{\circ} \mathrm{C}$ 에서 보관하였다.

\section{Protein assay}

단백질정량은 표준물질로 $\mathrm{BSA}$ 를 사용하여 protein assay kit(Bio-rad, USA)를 사용하여 측 정하였다.

\section{3. $\mathrm{NH}_{2}$-terminal amino acid sequence 확인}

분리된 $\mathrm{OPN}$ 단백질의 $\mathrm{NH}_{2}$-terminal amino acid sequence는 Applied Biosystem Model 491 protein sequencer(한국기초과학지원 연구원)를 이용하여 분석하였다.

\section{4. 산란계 면역}

$\mathrm{OPN}$ 에 대한 항혈청을 제조하기 위하여 산란 계의 면역은 35 주령 된 Single Comb White Leghorn(SCWL) 3수를 이용하여, Sunwoo 등 (1996)의 방법을 이용하였다. 항원으로서 OPN $1 \mathrm{mg}$ 을 $0.01 \mathrm{M}$ PBS buffer(pH 8.2)로 $1 \mathrm{~m} \ell$ 로 용해 시킨 후 동량의 Freund's complete adjuvant 
(Difco, USA)와 혼합한 후 산란계의 가슴근육 4 부위에 주사하였다. 2주 후에 다시 booster injection을 하기 위하여 항원은 1 차면역과 동일 양을 Freund's incomplete adjuvant(Difco, USA) 와 혼합하여 같은 방법으로 재주사 하고, 계란 은 매일 수집하여 $4^{\circ} \mathrm{C}$ 에 보관하여 사용하였다.

\section{5. $\lg Y$ 항체의 분리}

계란으로부터 anti-OPN $\operatorname{IgY}$ 는 Akita와 Nakai (1992)의 방법에 따라 water soluble fraction (WSF)에서 얻었다. 즉 계란의 난황을 증류수로 4 5배로 희석한 후 $\mathrm{pH}$ 를 5.0 으로 조정하여 4 ${ }^{\circ} \mathrm{C}$ 에서 6시간 동안 처리한 후 원심분리 $(10,000$ $\times \mathrm{g}, \quad 4^{\circ} \mathrm{C}, 25 \mathrm{~min}$ )하였다. 상등액을 Whatman No. 1 여과지로 여과한 후 동결건조하여 사용 하였다.

\section{6. 항체 역가 측정}

난황항체의 활성은 Mine(1997)과 $\mathrm{Li}$ 등(1998) 의 ELISA 방법을 약간 변형하여 측정하였다. 96 well의 microplate에 OPN 항원을 부착하기 위하여 각 well에 $\mathrm{OPN}$ 항원 $2 \mu \mathrm{g} / \mathrm{ml}$ 의 농도로 0.05M carbonate-bicarbonate buffer(pH 9.6)에 용 해하여 well당 $200 \mu \mathrm{l}$ 씩 주입하였다. 이것을 $4^{\circ} \mathrm{C}$ 에서 24시간동안 정치시킨 후 plate를 PBS-T buffer(Phosphate buffer saline, $0.05 \%$ Tween 20, $\mathrm{pH} 7.4)$ 로 3 회 세척하였다. 여기에 WSF를 증류 수로 1,000 배로 희석하여 plate에 주입한 후 37 ${ }^{\circ} \mathrm{C}$ 에서 1 시간동안 반응시킨 후 PBS-T buffer로 3회 세척하였다. 그런 다음 Alkaine phosphatase(AP)가 결합된 이차 항체인 rabbit antichicken IgG(Sigma, USA) 용액을 1,000 배로 희 석하여 $100 \mu$ l씩 well에 넣고 $37^{\circ} \mathrm{C}$ 에서 1 시간동 안 반응시킨 후 PBS-T buffer로 3회 세척하였 다. 다음으로 Alkaine phosphatase의 기질인 pnitrophenyl phosphate(Sigma, USA)을 넣고 $37^{\circ} \mathrm{C}$ 에서 10 분간 반응시킨 후 $3 \mathrm{~N} \mathrm{NaOH}$ 를 $50 \mu \mathrm{l}$ 씩
사용하여 반응을 정지시킨 다음 $405 \mathrm{~nm}$ 의 파장 에서 ELISA microplate reader(ELISA:ELx808: Bio-tec, USA)로 각 well의 흡광도를 측정하였 다.

\section{7. 우유 중의 $\mathrm{OPN}$ 함량 측정}

Radial immunodiffusion(RID)은 Sunwoo 등 (1996)의 방법을 약간 변형하여 실험하였다. $1.7 \mathrm{~m} \ell$ PBS buffer와 $0.3 \mathrm{~m} \ell$ anti-OPN IgY를 혼합 하여 $56^{\circ} \mathrm{C}$ 에서 가온하고, agarose $70 \mathrm{mg}$ 는 4.67 $\mathrm{m} \ell$ PBS buffer와 $0.35 \%$ sodium azide $0.4 \mathrm{~m} \ell$ 를 혼합하여 완전히 녹을 때까지 중탕하고, 그 후 두 용액을 완전히 섞어 준비된 RID plate에 부 어 gel이 될 때까지 기다린다. RID plate에서 gel 상태로 굳으면 직경이 $2.5 \mathrm{~mm}$ 가 되게 구멍 을 똟어 분리한 $\mathrm{OPN}$ 을 $10,20,40,80 \mu \mathrm{g}$ 의 농 도로 각각 $6 \mu$ 씩 주입하여 3 일간 상온에서 배 양한다. 배양이 완료되면 RID plate에 주입한 액이 확산에 의해 만들어진 침강선의 직경을 측정하여 OPN 표준정량곡선을 작성하였다. 또 한 같은 방법으로 우유 중의 $\mathrm{OPN}$ 함량을 표준 정량곡선으로부터 계산하였다.

\section{8. $\mathrm{OPN}$ 의 가용화 능력 검정}

內藤(1986)의 방법에 준하여 $20 \mathrm{mM} \mathrm{CaCl}_{2}$ $0.25 \mathrm{~m} \ell$ 에 CPP(明治製菓株式會社, Japan), polyglutamicacid(Sigma, USA), OPN을 각각 $1 \mathrm{mg}$ 을 첨가한 후, $20 \mathrm{mM}$ Na-phosphate buffer( $\mathrm{pH} 7.0)$ $1 \mathrm{~m} \ell$ 를 첨가하였다. 소장하부의 조건 $(\mathrm{pH}$ 7.0. 37 $\left.{ }^{\circ} \mathrm{C}\right)$ 을 유지시켜 주면서 $0,2,4,6,8,24$ 시간에 시료를 채취하여 $10,000 \times \mathrm{g}$ 에서 10 분간 원심분 리한 후, 상등액만을 취하여 ICP Emission Sectro Analyzer(JY 38 Plus. ISA, Jobin Yvon, France)로 3회 반복 측정하여 평균값을 구하였 다. 


\section{III. 결과 및 고찰}

\section{1. 우유로부터 OPN의 분리·정제}

우유에서 $\mathrm{OPN}$ 단백질을 분리 - 정제하기 위 하여 ion-exchange chromatography인 DEAESephacel과 hydrophobic chromatography인 PhanylSepharose을 이용하였으며, 각 단계별 정제도는 SDS-PAGE에 의하여 확인하였다(Fig. 1).

Lane 1은 DEAE-Sephacel column을 이용하여 정제한 protein의 band를 나타낸 것으로 분자량 60,000 dalton 정도인 $\mathrm{OPN}$ 이라고 추측되는 물질 이 있는 것을 확인 할 수 있었으나 다른 protein band가 많았다. 다시 순도를 높이기 위 하여 Phenyl-Sepharose column 2개를 거쳐 정 제한 결과 Lane 3 에서 보는 것과 같이 $\mathrm{OPN}$ 이 외의 다른 protein band 없이 순수한 단백질을 얻을 수 있었다.

또한 정제단계별 단백질 정량은 Table 1에서 보는 것과 같다. 우유 $1 \ell$ 에서 최종 $5.7 \mathrm{mg}$ 의 순수한 $\mathrm{OPN}$ 을 얻었다. 정제과정에서 $\mathrm{OPN}$ 의 확인은 분자량만을 기준으로 하였기 때문에 $\mathrm{OPN}$ 의 정량은 최종 단계에서만 하였다. 한편 Bayless 등(1977)에 의하면 우유 $1 \ell$ 에서 약 $8 \mathrm{mg}$ 의 순수한 $\mathrm{OPN}$ 을 얻었으며, Senger 등 (1989)도 모유에서 $3 \sim 10 \mathrm{mg} / \ell$ 를 분리하였다. 따라서 우유나 모유 속에는 정제된 양보다는 많겠지만, 미량 존재하는 단백질임을 알 수 있 다.

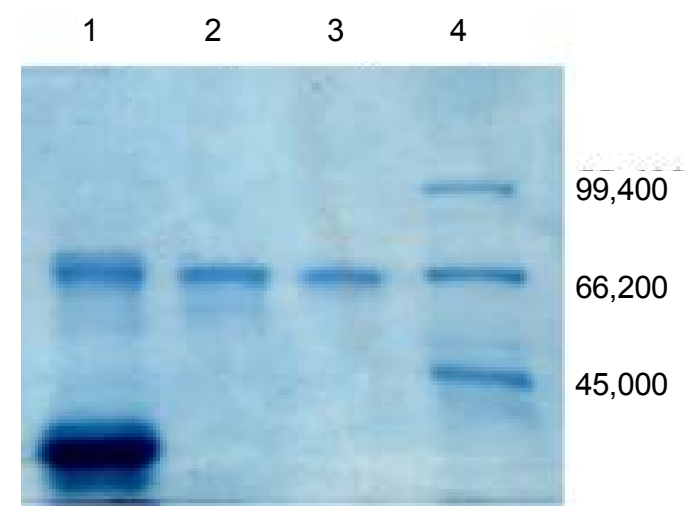

Fig. 1. SDS-PAGE analysis of purification from bovine milk.

1 : Purification by DEAE-Sephacel from bovine milk

2 : Purification by Phenyl-Sepharose I from bovine milk

3 : Purification by Phenyl-Sepharose $\Pi$ from bovine milk

4 : Low molecular weight marker(Bio-rad, USA).

\section{N-terminal sequence 확인}

분자량을 기준으로 하여 우유에서 분리 - 정 제한 protein이 $\mathrm{OPN}$ 인지를 더욱 정확히 확인하 기 위해서 N-terminal amio acid sequence을 확 인한 결과 Leu-Pro-Val-Lys-Pro-Thr-Ser으로 판 명되었다. 이것은 $\operatorname{Kerr}(1991)$ 등에 의해 알려진 $\mathrm{OPN}$ 의 N-terminal amio acid sequence와 대조한 결과 $\mathrm{OPN}$ 의 N-terminal amio acid sequence 7 개 의 순서가 일치하였다. 따라서 본 실험에서 분 리 · 정제한 단백질이 $\operatorname{Kerr}(1991)$ 등에 의해 알 려진 OPN과 동일 물질임을 확인하였다.

Table 1. Purification of Osteopontin from Bovine milk

\begin{tabular}{lccc}
\hline & $\begin{array}{c}\text { volume } \\
(\mathrm{m} \ell)\end{array}$ & $\begin{array}{c}\text { Protein } \\
(\mathrm{mg})\end{array}$ & $\begin{array}{c}\text { OPN } \\
(\mathrm{mg})\end{array}$ \\
\hline \hline Starting material & 1000 & 20300 & - \\
DEAE-Sephacel & 112 & 251 & - \\
Phenyl-Sepharose I & 70 & 16.7 & 5.7 \\
Phenyl-Sepharose II & 15 & 5.7 & 5 \\
\hline
\end{tabular}


3. 난황내의 Anti-OPN IgY 항체의 확인

항원인 $\mathrm{OPN}$ 으로 면역된 산란계에서 생산된 계란의 anti-OPN $\mathrm{IgY}$ 항체의 역가를 ELISA로 측정하였다(Fig. 2). OPN을 주사 후 항체가 조 금씩 높아지다가 1 차 면역 후 14 일째에 2차 추 가면역(boosting)을 함으로써 다시 역가가 상승 하여 42일째에 가장 높은 항체 역가를 보였다. 이것은 Shimizu 등(1998)이 E. coli O142: K86: $\mathrm{H} 6$ 의 사균을 주사한 후 계란의 anti-E.coli O142: K86: H6의 항체역가를 ELISA를 이용하 여 측정한 결과 면역 주사 후에는 계속 증가하 는 경향을 보이다 40 일 경에 최고치를 나타내 다가 차츰 감소하는 경향을 나타냈다는 보고와 비슷한 결과를 보였다.

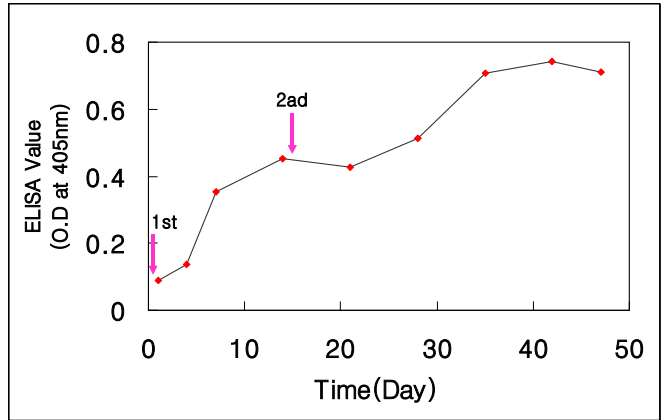

Fig. 2. Changes of antibody activity in egg yolk during the immunization period. Anti-OPN antibody activity in egg yolk were measured by ELISA. The arrows indicate 0,14 days when injected with OPN.

\section{4. 우유의 $\mathrm{OPN}$ 함량 측정}

우유에 존재하는 $\mathrm{OPN}$ 의 함량은 RID 방법을 사용하여 측정하였다(Fig. 3). 이것은 anti-OPN $\mathrm{IgY}$ 와 $\mathrm{OPN}$ 의 화학적 반응에 의한 radial 형태 로 침강선이 형성되는 것을 이용하였다. AntiOPN IgY 항체를 agarose gel에 혼합한 후 분 리 - 정제된 $\mathrm{OPN}$ 을 각 well에 $10 \sim 80 \mu \mathrm{g}$ 을 주입 후 나타나는 침강선의 직경으로부터 Fig. 4에서
보는 것과 같이 $\mathrm{OPN}$ 의 정량곡선을 작성하고 이 곡선에 의해 우유 중의 $\mathrm{OPN}$ 함량을 정량하 였다. 그 결과 원유, 탈지유, 시유에서 각각 $39.78,31.74,37.48 \mu \mathrm{g} / \mathrm{m} \ell$ 을 함유하고 있는 것으 로 나타났다(Table 2), 탈지유에서 약간 낮은 OPN 함량은 탈지과정에서 단백질의 일부가 소 실됨을 의미한다. 한편 $\mathrm{OPN}$ 으로 면역된 계란 에서 분리한 anti-OPN $\operatorname{IgY}$ 를 이용한 우유 중 $\mathrm{OPN}$ 의 함량 분석기법으로 활용할 수 있을 것 으로 생각되어진다.

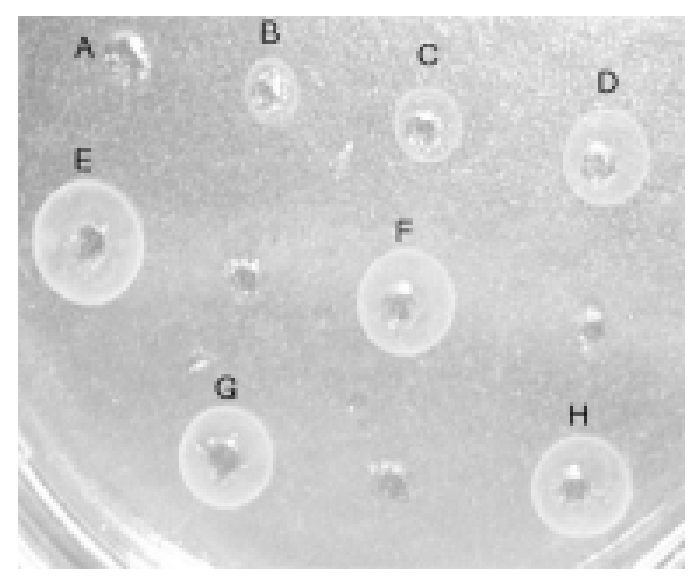

Fig. 3. Single radial immunodiffusion patterns of anti-OPN $\lg Y$ against OPN dilution.
A : OPN
C : OPN $20 \mu \mathrm{g}$
B : OPN $10 \mu \mathrm{g}$
E : OPN $80 \mu \mathrm{g}$
D : OPN $40 \mu \mathrm{g}$
G : Skim milk
F : Raw milk
$\mathrm{H}$ : Market milk.

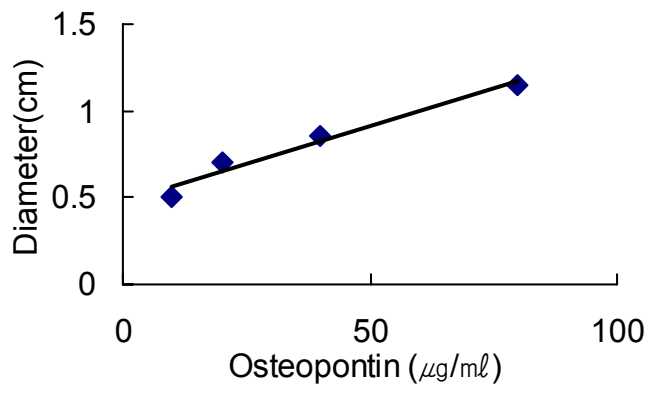

Fig. 4. Standard curve of OPN in single radial immunodiffusion. 
Table 2. OPN concentration in bovine milk by radial immunodiffusion

$(\mu \mathrm{g} / \mathrm{m} \ell)$

\begin{tabular}{cccc}
\hline & Raw milk & Skim milk & Market milk \\
\hline \hline OPN & 39.78 & 31.74 & 37.48 \\
\hline
\end{tabular}

5. $\mathrm{OPN}$ 의 가용화 능력 검정

In vitro 실험을 통해 $\mathrm{OPN}$ 이 $\mathrm{Ca}-\mathrm{P}$ 의 결합에 의한 침전을 저지하는 능력, 즉 칼슘가용화 정 도를 측정하였다(Fig. 5). 분자구조상으로 칼슘 가용화 능력을 나타낼 수 있는 negative charge 를 가진 펩타이드인 poly-glutamic acid와 $\mathrm{CPP}$ 의 $\mathrm{Ca}$ 가용화 능력을 $\mathrm{OPN}$ 과 비교하였다.

시간별로 $\mathrm{Ca}$ 가용화 능력 정도를 살펴볼 때 시간이 지남에 따라 $\mathrm{Ca}$ 가용화 능력은 점차 감 소하는 경향이 나타났으며, 6시간 이후로는 $\mathrm{OPN}$ 을 제외한 물질들의 $\mathrm{Ca}$ 가용화 능력은 현 저히 떨어져 대조구와 비슷하였다. 이와 같은 결과는 $\mathrm{OPN}$ 이 기존에 $\mathrm{Ca}$ 가용화 능력이 좋다 고 알려진 poly-glutamic acid나 $\mathrm{CPP}$ 보다 더욱 우수한 것이며 이는 $\mathrm{OPN}$ 의 화학적구조가 $\mathrm{Ca}$ 가용화에 더욱 적합한 것으로 사료되었다.

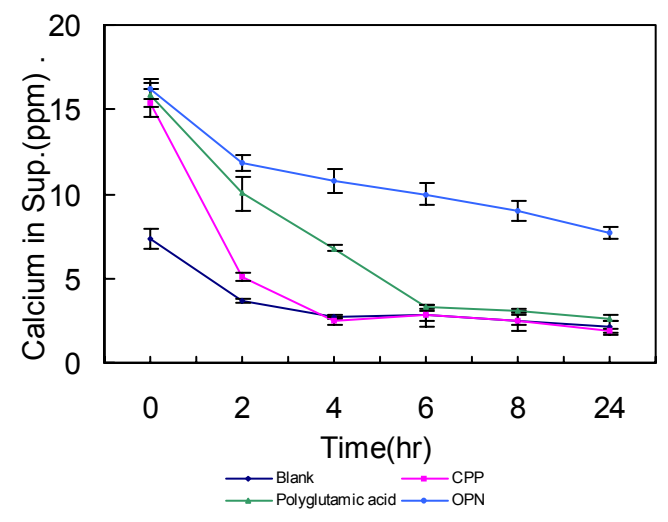

Fig. 5. Inhibition with OPN on the precipitation of calcium in vitro at physiological $\mathrm{pH}$.
IV. 요 약

본 연구는 우유로부터 $\mathrm{OPN}$ 을 분리·정제하 여 그 특성을 규명하기 위해서 수행되었다. 먼 저 ion-exchange와 hydrophobic chromatography 를 이용하여 우유로부터 $\mathrm{OPN}$ 을 분리·정제하 였다. $\mathrm{OPN}$ 의 분자량은 $\mathrm{SDS}$-전기영동 상에서 약 60,000dalton이었고, $\mathrm{NH}_{2}$-terminal amino acid sequence를 확인한 결과 Leu-Pro-Val-Lys-ProThr-Ser 순이었다. OPN을 35주령된 SCWL를 이용하여 산란계를 면역 시키고, 형성된 antiOPN $\operatorname{IgY}$ 항체를 분리·정제한 후 ELISA test 로 항체가를 측정하였다. 또한 RID test을 이용 하여 $\mathrm{OPN}$ 함량에 따른 정량곡선을 작성하고, 이 곡선에 의해 우유 중 OPN 함량을 정량하였 다. 그 결과 원유, 탈지유, 시유에서 각각 39.78 , $31.74,37.48 \mu \mathrm{g} / \mathrm{m} \ell$ 을 함유하고 있는 것으로 나 타났다. 또한 $\mathrm{OPN}$ 의 $\mathrm{Ca}$ 가용화 능력을 검정한 결과 $\mathrm{OPN}$ 이 $\mathrm{CPP}$ 와 poly-glutamic acid 보다 더 우수한 것으로 나타났다.

\section{$\mathrm{V}$. 인 용 문 헌}

1. Abd El-Salam, M. H., El-Shibiny, S. and Buchheim, W. 1996. Characteristics and potential uses of the casein macropeptide. Int. Dairy J. 6: 327-341.

2. Akita, E. M. and Nakai, S. 1992 Immunoglobulins from egg yolk : isolation and purification J. Food Sci. 57:629-634.

3. Bayless, K. J., Davis, G. E. and Meininger, G. A. 
1997. Isolation and biological properties of osteopontin from bovine milk. Protein Expr. and Puri. 9:309-314.

4. Bergeim O. V. 1926. Carbohydrates and calcium and phosphorus. J. Biol. Chem. 70:35-45.

5. Bronner, F. 1987. Intestinal calcium absorption: Mechanisms and applications. J. Nutr. 117(8): 1347-1352.

6. Brown, L. F., Berse, B., Van de Water, L., Papadolos-Sergiou, A., Perruzi, C. A., Manseau, E. J., Dvorak, H. F. and Senger, D. R. 1992. Expression and distribution of osteopontin in human tissues; widespread association with luminal epithelial surfaces. Mol. Biol. Cell. 3: 1169-1180.

7. Denhardt, D. T. and Guo, X. 1993. Osteopontin: a protein with diverse functions. FASEB. J. 7 : 1475-1482.

8. Fisher, L. W., Hawkins, G. R., Tuross, N. and Termine, J. D. 1987. Purification and partial characterization of small proteoglycans I and II, bone sialoproteins I and II, and osteonectin from the mineral compartment of developing human bone. J. Biol. Chem. 262:9702-9708.

9. Franzen, A. and Heinegard, D. 1985. Isolation and characterization of two sialoproteins present only in bone calcified matrix. Biochm. J. 232:715-724.

10. Kerr, J. M., Fisher, L. W., Termine, J. D. and Young, M. F. 1991. The cDNA cloning and RNA distribution of bovine osteopontin. Gene 108 : 237-243.

11. Kitts, D. D. and Yuan, Y. V. 1992. Casein phosphopeptides and calcium bioavailability. Trends in Food Sci. Technol. 3:31-36.

12. Kline, O. L., Keenan, J. A., Elevehjem, C. A. and Hart, E. B. 1932. Lactose in nutrition. J. Biol. Chem. 98:121-131.

13. Li, X., Nakano, T., Sunwoo, H. H. and Sim, J. S. 1998. Effects of egg yolk weights on yolk antibody $(\operatorname{IgY})$ production in laying chickens. Poult. Sci. 77:226-270.

14. Mine, Y. 1997. Separation of Salmonella enteritidis from experimentally contaminated liquid eggs using a hen IgY immobilized immu- nomagenetic esparation system. J. Agric. Food Chem. 45:3723-3727.

15. Naito, H., Kawakami, A. and Imamura, T. 1972. In vivo formation of phosphopeptide with calciumbinding property in the small intestinal tract of the rat fed on casein. Agr. Biol. Chem. 36:409415.

16. Oldberg, A., Franzen, A. and Heinegard, D. 1986. Cloning and sequence analysis of rat bone sialoprotein(osteopontin) cDNA reveals an ArgGly-Asp cell binding sequence. Proc. Natl. Acad. Sci. USA. 83:8819-8823.

17. Reeves, R. E. and Latour, N. G. 1958. Calcium phosphate sequestering phosphopeptide form casein. Science. 128:472-472.

18. Reinholt, F. P., Hultenby, K., Oldberg, A. and Heinegard, D. 1990. Osteopontin-a possible anchor of osteoclasts to bone. Natl. Acad. Sci. USA. 87: 4473-4475.

19. Senger, D. R., Perruzzi, C. A., Papadopoulos, A. and Tenen, D. G. 1998. Purification of a human milk protein closely similar to rumor-serceted phosphoproteins and osteopontin. Biochim. Biophys. Acta 996:43-48.

20. Shimizu, M., Fitzsimmons, R. C. and Nakai, S. 1988. Anti-E. coli immunoglobulin $\mathrm{Y}$ isolated from egg yolk of immunized chickens as a prtential food ingredient. J. Food Sci. 53:1360-1366.

21. Shiraga, H., Min, W., WanDuse, W. J., Clayman, M. D., Miner, D., Terrell, C. H., Sherbotie, J. R., Foreman, J. W., Przysieeki, C, Neilson, E. G. and Hoyer, J. R. 1992. Inhibition of calcium oxalate crystal growth in vitro by uropontin, an new member of the aspartic acid-rich protein superfamily. Proc. Natl. Acad. Sci. USA. 89:426430.

22. Sorensen, E. S. and Petersen, T. E. 1993. Purification and characterization of three proteins isolated from the proteose peptone fraction of bovine milk. J. Dairy Res. 60:189-197.

23. Sorensen, E. S. and Petersen, T. E. 1995. Phosphorylation, glycosylation, and trans-glutaminase sites in bovine osteopontin ${ }^{\mathrm{a}}$. The New York Academy of Sciences. 760:363-366. 
24. Sunwoo, H. H., Nakano, T., Dixon, W. T. and Sim, J. S. 1996. Immune responses in chickens against lipopolysacharide of escherichia coli and salmonella tryphimurium. Poult. Sci. 75:342-345.

25. Zimolo, Z., Wesolowski, G., Tanaka, H., Hyman, J., Hoyer J. R. and Rodan, G. A. 1994. Soluble avß3 integrin ligands increase intracellular $\left(\mathrm{Ca}^{++}\right)$ in rat osteoclasts and mouse derived osteoclastlike cells. Am. J. Physiol. 266:376-381.

26. 內藤. 1986. カゼィンの 消化時生成するホスホ ペプチドのカルシウム 吸收促進機構. 日本營養 食糧學會紙. 39(6):433-439.

(접수일자 : 2003. 1. 20 / 채택일자 : 2003. 4. 15) 